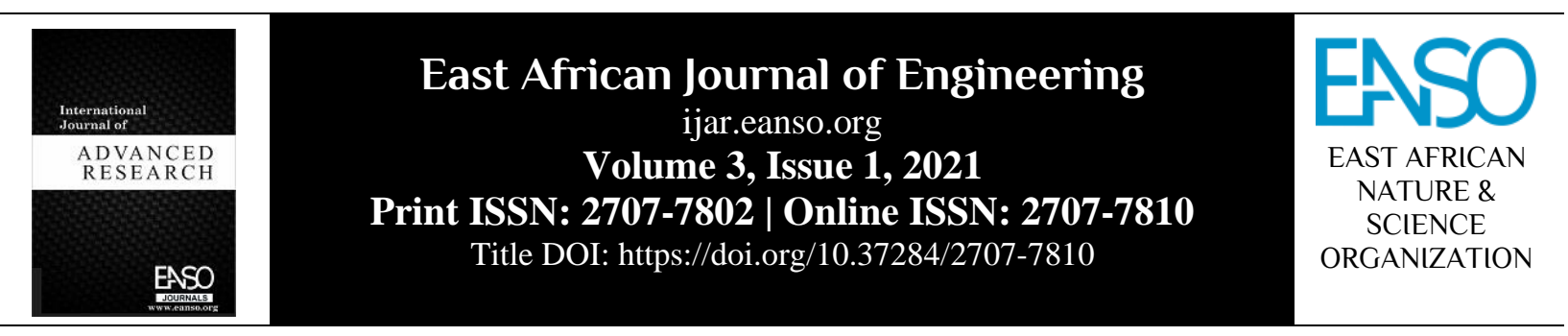

Original Article

\title{
Coal-Key Energy Resource for the Future in Kenya? A Review
}

\author{
Dorcas Wambui Kariuki ${ }^{1 *}$, \& John Muna Kuria ${ }^{2}$ \\ ${ }^{1}$ Murang'a University of Technology, P. O. Box 75-10200, Murang'a, Kenya. \\ ${ }^{2}$ Kenyatta University, P. O. Box 43844-00100, Nairobi, Kenya. \\ *ORCID ID: https://orcid.org/0000-0002-5696-0866; Author for Correspondence Email: kariuki.dorcas55@ gmail.com.
}

Article DOI: https://doi.org/10.37284/ijar.3.1.319

\section{Publication Date: ABSTRACT}

16 Apr 2021 Coal has been a major contributor to energy security in many developed Keywords: countries and is projected to continue contributing a significant fraction of global energy demand in the foreseeable future. Although coal power

Coal, generation has been associated with numerous environmental implications, technological advances in the mining sector have enabled the mining of coal sustainable mining, energy security, Kenya, economic growth. with minimal environmental impacts, especially in major coal-producing countries. In Kenya where inadequate energy supply is a major deterrent to economic growth, the discovery of coal reserves in the country presents a suitable opportunity for the country to address its energy security challenges. The challenge is how the exploitation of this resource can be done sustainably. This article explores the potential for sustainable coal mining in Kenya to address energy security challenges in the country. However, as it will be discussed in the paper, sustainable coal mining is often met with many challenges which include lack of finances, lack of technology, poor conditions of the physical environment, and unsupportive laws and regulations. Therefore, the article concludes that there are adequate ways and technologies that can be adapted in Kenya for sustainable coal mining. However, the decision as to whether coal mining should be embraced in the country should put into consideration the amount and nature of available coal reserves, availability of finances, availability of technologies, physical environmental conditions and the associated laws and regulations.

\section{APA CITATION}

Kariuki, D. W., \& Kuria, J. M. (2021). Coal-Key Energy Resource for the Future in Kenya? A Review. East African Journal of Engineering, 3(1), 72-85. https://doi.org/10.37284/ijar.3.1.319

\section{CHICAGO CITATION}

Kariuki, Dorcas Wambui, and Kuria John Muna. 2021. "Coal-Key Energy Resource for the Future in Kenya? A Review”. East African Journal of Engineering 3 (1), 72-85. https://doi.org/10.37284/ijar.3.1.319. 
International Journal of Advanced Research, Volume 3, Issue 1, 2021

Article DOI: https://doi.org/10.37284/ijar.3.1.319

HARVARD CITATION

Kariuki, D. W., and Kuria, J. M. (2021) “Coal-Key Energy Resource for the Future in Kenya? A Review”, East African Journal of Engineering, 3(1), pp. 72-85. doi: 10.37284/ijar.3.1.319.

\section{IEEE CITATION}

D. W. Kariuki, and J. M. Kuria, "Coal-Key Energy Resource for the Future in Kenya? A Review", EAJE, vol. 3, no. 1, pp. 7285, Apr 2021.

\section{MLA CITATION}

Kariuki, Dorcas Wambui, and Kuria John Muna. "Coal-Key Energy Resource for the Future in Kenya? A Review”. East African Journal of Engineering, Vol. 3, no. 1, Apr 2021, pp. 72-85, doi:10.37284/ijar.3.1.319.

\section{INTRODUCTION}

\section{Kenya's Energy Situation and Coal Reserves}

The adequacy, security, and price competitiveness of electricity are vital aspects that influence a country's economic growth and development. In Kenya, low installed power generation capacity is a significant constraint to economic growth. According to Oxford Business Group (2015), in 2015, the country's installed power generating capacity was 2,164 MW which served 45 million people, this has however increased significantly to
2,712 MW by December 2018 (EPRA, 2019). Electricity contributes only $5.9 \%$ of the total energy consumed in the country, $80 \%$ of which is generated from renewable sources - geothermal, thermal and hydropower (Basu et al., 2016). Table 1 below shows electricity installed capacity in Kenya from 2013 to 2018. Imported coal for use in cement manufacturing industries contributes less than $1 \%$ of the primary energy consumed in Kenya (Ministry of Energy and Petroleum, 2015), biomass is the main source of energy at $74.6 \%$ while petroleum contributes $19.1 \%$ of the primary energy consumed in the country (Kiplagat et al., 2011).

Table 1: Electricity installed capacity (MW) in Kenya from 2013 to 2018

\begin{tabular}{|c|c|c|c|c|c|c|c|}
\hline \multirow[b]{2}{*}{ Year } & \multicolumn{7}{|c|}{ Installed capacity (MW) } \\
\hline & Hydro & Thermal oil & Geothermal & Wind & Co-generation & Solar & Total \\
\hline 2013 & 812.3 & 714.4 & 241.8 & 26.3 & 26 & - & 1820.8 \\
\hline 2014 & 818.3 & 751.3 & 573.4 & 26.3 & 26.0 & - & 2195.3 \\
\hline 2015 & 820.4 & 833.6 & 627.0 & 26.1 & 26.0 & 0.6 & 2333.7 \\
\hline 2016 & 818.7 & 801.6 & 652.0 & 26.1 & 28.0 & 0.6 & 2327.0 \\
\hline 2017 & 826.2 & 806.9 & 652.0 & 26.1 & 28.0 & 0.7 & 2339.9 \\
\hline 2018 & 826.2 & 807.7 & 663 & 336.1 & 28 & 50.7 & 2711.7 \\
\hline
\end{tabular}

Source: (EPRA, 2019)

Due to increasing economic activities and the continued rise in the human population in Kenya, the demand for domestic energy in the country has been rising rapidly and is mostly satisfied through foreign energy imports. As a result, the country's economic growth rate is significantly slowed down due to the high costs of energy imports involved (Eije \& Mokveld, 2018). For example, the importation of crude petroleum for use in transport, industrial and commercial sectors accounts for $25 \%$ of the country's import bill. Consequently, unreliability in energy supply due to the high costs involved is a major concern in the country as it negatively impacts industrial productivity, more so in the manufacturing sector. For instance, it is estimated that Kenya's companies lose about 10\% of their production capacity due to power outages and fluctuations (Eije \& Mokveld, 2018).

Kenya's existing capacity to generate electricity is not able to keep up with the ever-increasing demand. With more than $39 \%$ of the country's electricity coming from hydropower (Eije \& Mokveld, 2018), electricity production is particularly most affected during summer when the water levels are low. Consequently, capacity gaps are met through thermal electricity generation that relies on fossil fuels; which is more expensive 
compared to other renewable sources such as hydropower. For example, the total quantity of petroleum products (crude petroleum, petroleum fuels, lubricating oils and lubricating gases) imported into the country increased from 3.976 tonnes in 2008 to 6.114 tonnes in 2018 (EPRA, 2019), which is an increase of $53.8 \%$ within 10 years.

According to the Kenya government, coal is a key energy source that will drive towards the achievement of the country's Vision 2030. Recently, coal reserves were discovered in the Mui Basin of Kitui County, Kenya; and are sub-divided into four blocks (A, B, C and D) for exploration and exploitation. According to the Ministry of Energy and Petroleum (2015), Block C was confirmed to hold 400 million tons of coal reserves whose quality ranges from lignite to sub-bituminous of calorific values $16-27 \mathrm{MJ} / \mathrm{Kg}$. Further, 31 blocks of coal have been established in the Taru Basin located in the Coastal region of Kenya - these are being explored for their coal generation potential before being earmarked for coal production (Ministry of Energy and Petroleum, 2015).

Because of the vast coal reserves available, the Government of Kenya plans to generate at least $4500 \mathrm{MW}$ of electricity from coal by 2030 . In this regard, the Government has started the construction of a $1050 \mathrm{MW}$ coal-fired power plant in Lamu County which is expected to generate 7,308,249 MWh of electricity annually (Ministry of Energy and Petroleum, 2015). However, owing to the nature of coal discoveries, the country will face many challenges in the development of the coal sector (Ministry of Energy and Petroleum, 2015). These challenges range from lack of expertise, lack of infrastructure, inadequate technical capacity, inadequate power supply, lack of capacity to handle the products of coal combustion, inadequate financial capacity and lack of adequate coal handling facilities.

According to Torrie (2014), based on the Levelised Cost of Energy calculator (LCOE), coal is the $5^{\text {th }}$ most economical source of electricity after wind, nuclear, solar photovoltaic and biomass in Kenya. On the other hand, based on TVM LCOE; coal, biomass, nuclear and combined gas cycle are at par in terms of economic production (Torrie, 2014).
This means that coal is not the most economical source of energy given that under high carbon tax scenario, \$30 (Torrie, 2014) or CCT, 2-3CkWh (Jaccard, 2006), it is the most expensive energy source. Why then should Kenya consider 'clean coal' as an option for energy generation at a time when most countries are moving towards renewable energy generation?

Energy security for any country is characterised by two features; long-term security or the availability of resources, and short-term security characterised by disruption of energy generation (Reddy, 2013). The diversification of energy sources is, therefore, one of the drivers of secure energy supply and economic development for any Country (Coal Association of Canada, 2012). Coal power production in Kenya is, therefore, an opportunity for the Country to diversify its energy sources with the intention to enhance her energy security.

Although many challenges are expected to come along with coal power production in Kenya and none of them should be overlooked, this article will focus on the efficiency and cleanliness aspect of coal power generation in Kenya-in terms of environmental implications during mining. In essence, the article will discuss potentially sustainable coal mining techniques to enable coal power generation for enhanced energy security in Kenya. The motivation for this focus is that although much attention has been given to Greenhouse gas GHGs reduction during coal combustion to minimise environmental impacts (Jaccard, 2006), we cannot afford to ignore the aspect of cleanliness during coal mining (MacKay, 2008).

\section{Background of Coal Mining}

Coal is considered to be a non-renewable source of energy because its formation takes millions of years. The mining of coal involves the use of large machinery to remove coal from the earth, depending on the location of the coal reserves on the ground. The two main methods of coal mining are surface mining which is used when coal reserves are located less than 200 feet underground and underground mining/deep mining which is applicable when the coal reserves are located more than 200 feet underground. Apart from the possibility for the 
collapse of mine tunnels and acid water drainage in abandoned underground mines, underground mining is generally considered less environmentally harmful than surface mining (U.S. EIA, 2020).

Coal mining is considered useful for national economic development, but not necessarily so at regional levels. According to Williams \& Nikijuluw (2020), at national levels, coal mining is a major contributor to income generation, creation of employment and government royalties; while at regional levels, coal mining is considered to exert pressure on the physical environment, housing sector, job markets and other public services. For example, coal mining and combustion are associated with a wide range of harmful environmental impacts. Coal is the dirtiest fossil fuel, and its environmental pollution potential is relatively high as its mining causes land degradation and waste generation while its combustion releases several GHGs. Main activities of coal mining which include road construction, drilling, seismic testing, transportation and waste disposal negatively impact on flora, fauna, land/soil, air quality, groundwater and surface water (Jaccard, 2006).

According to MacKay (2008), coal mining releases significant amounts of carbon dioxide, methane and carbon monoxide from exposed coal seams, castoff mudstones and shales which add up to $2 \%$ global GHGs emissions. Additionally, coal mining results in coal waste heaps which causes landscape instability and erosion (Song et al., 2015), potential explosion accidents causing death and injuries (Ciesielczuk et al., 2015), soil and groundwater contamination (Banerjee, 2014; Chugh \& Behum, 2014), and habitat destruction (Adibee et al., 2013). For example, in a study conducted in Central Indus Basin in Pakistan, Jabbar Khan et al. (2020) found that the presence of potentially toxic elements such as copper, cadmium, iron and Sulphur in coal mines can lead to the degradation of ecological resource quality, and consequently adversely impact on human health.

\section{SUSTAINABLE COAL MINING TECHNIQUES AND LAND DEGRADATION AMELIORATION}

\section{Mechanised Solid Dense Stowing Underground Coal Mining versus Traditional Underground Coal Mining and Opencast Mining}

Opencast mining is a surface mining method that involves rocks or mineral extraction from the earth which results in the formation of an open pit or burrow. Unlike other extractive methods, opencast mining is used when commercially useful rocks or minerals are deposited near the surface, in which case the overburden is relatively thin or the materials of interest are not suitably structured for tunnelling. However, most coal seams are located deep down the ground and cannot be reached through opencast mining. Additionally, the use of traditional underground coal mining methods such as longwall mining, blast mining, short wall mining and retreat mining has been associated with as many negative environmental impacts as those of opencast mining (Massachusetts Institute of Technology, 2016). Some of these environmental and social impacts associated with opencast coal mining include massive clearance of vegetation/overburden removal, accumulation of waste dumps, displacement of people, contamination of ground and surface water, noise pollution and dust generation (Drebenstedt, 2001; Chaulya \& Prasad, 2016).

The fully mechanised solid dense stowing underground coal mining is an underground coal mining technology whose use minimises environmental impacts associated with underground coal mining. It incorporates a coal mining supporter and goaf stowing hydraulic supporters as shown in Figure 1. These enable coal mining and backfilling of solid material (gangue, fly ash and other coal mining solid wastes) simultaneously at the work face while at the same time providing support to the roof of the gob area (Huang et al., 2017).

The fully mechanised system provides the following coal mining benefits that would otherwise not be realised using traditional underground or opencast mining methods (Zhang et al., 2015); (Huang et al., 2017); 
- Prevention of surface subsidence is usually brought about by the goaf roof.

- Enhancement of ecological and environmental sustainability of the mining area through the reduction in mining wasteland occupation, reduction in soil and water contamination through leaching, and reduction in air pollution from mine waste combustion.
- Minimises the need for displacement of villages and residential areas and enables the extraction of "under three" coal resources - underwaters, railways and buildings.

- Minimises the costs of land acquisition, costs of handling mine waste, damages from land subsidence, and the costs of resettlement of people from subsided areas.

\section{Figure 1: Structure of backfilling hydraulic supporter}

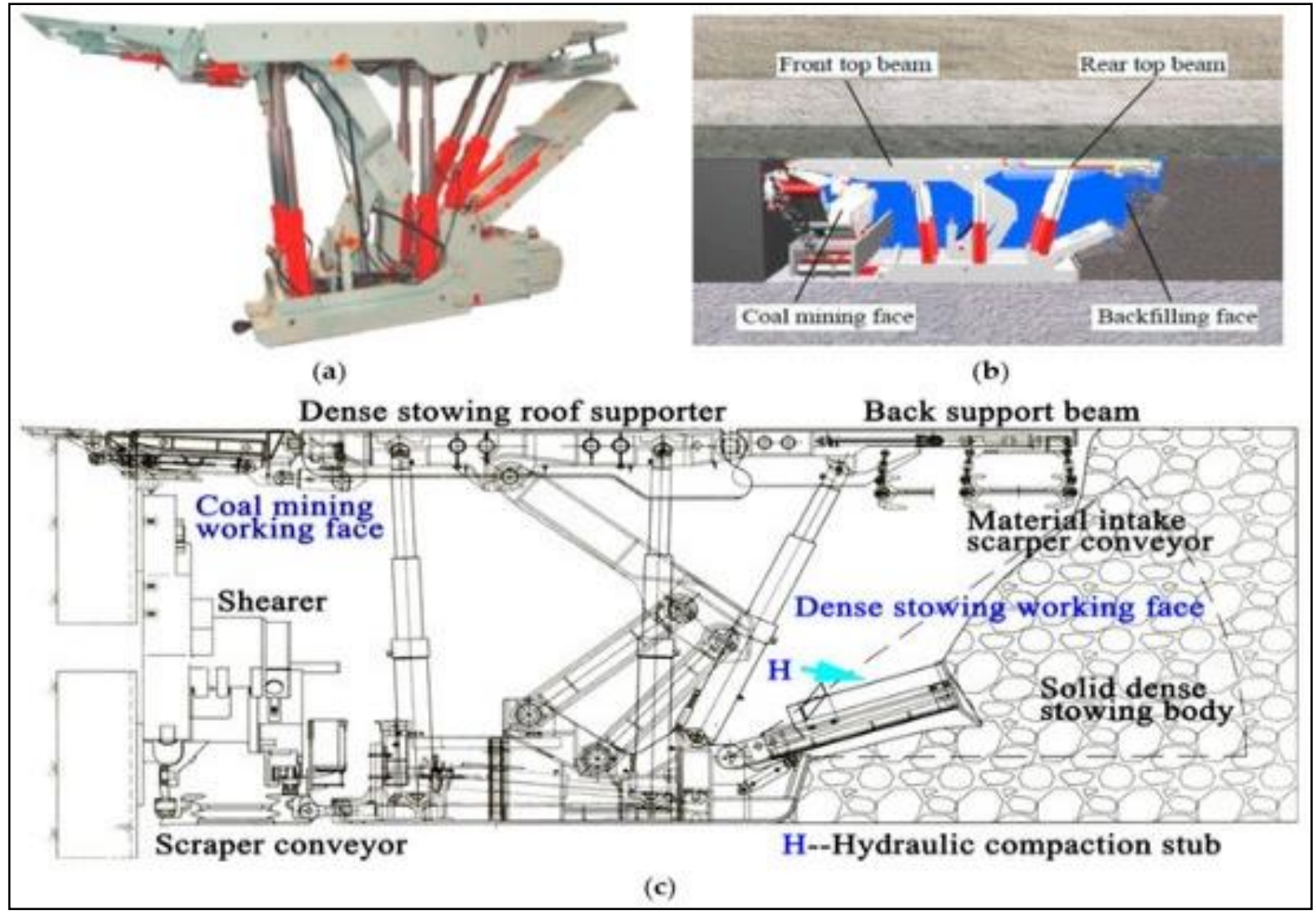

Source: (Huang et al., 2017)

However, because this technique is suitable for coal seams located deep down the ground, its suitability for use in Kenya's coal mining will depend on the amount, nature and location of coal reserves on the ground. This means that this technology might not be useful for Kenya if its coal reserves are located near the surface, which implies that the use of open cast mining is the best option. In this case, the country should be in a position to address the environmental impacts of opencast mining through land reclamation, restoration and rehabilitation, and mine waste handling as described below.

\section{Land Reclamation, Restoration and Rehabilitation}

Land reclamation is a suitable way of reducing land degradation impacts from coal mining and easing the process of land acquisition for the coal industry. Land reclamation refers to the process of returning a mine into its pre-mining state through backfilling of rock overburden on an impervious ground,

76 | This work is licensed under a Creative Commons Attribution 4.0 International License. 
stabilising and levelling it to its previous topography, then compacting and covering it with a layer of topsoil (Singh et al., 2017). This process allows for the establishment of previous vegetation through a process called biological reclamation which then makes the land habitable for previous flora and fauna.

For example, in Europe, $50 \%$ of former coal mines were reclaimed to grasslands and forests while in China, $70 \%$ of coal mines are reclaimed for agricultural use due to a shortage of agricultural land (Bian et al., 2010). However, in deep soil layers $(60 \mathrm{~cm}-100 \mathrm{~cm})$, coal mines reclaimed for forestry purposes were found to mimic pre-mining soil properties more than those reclaimed for agricultural or grassland purposes (Liu et al., 2017). This means that the choice of reclaimed land-use type is a critical factor that is likely to influence the physical environment and socio-economic conditions.

Elsewhere, to address the problem associated with abandoned exposed coal mines and to ease the process of land acquisition for mining in India, Singh et al. (2017)) proposed a corporate social responsibility activity of the coal industry whereby after coal mining, the land is reclaimed and returned to the owners or the government as shown in Figure 2 below.

Figure 2: Land reclamation and handing over to the government or the owner

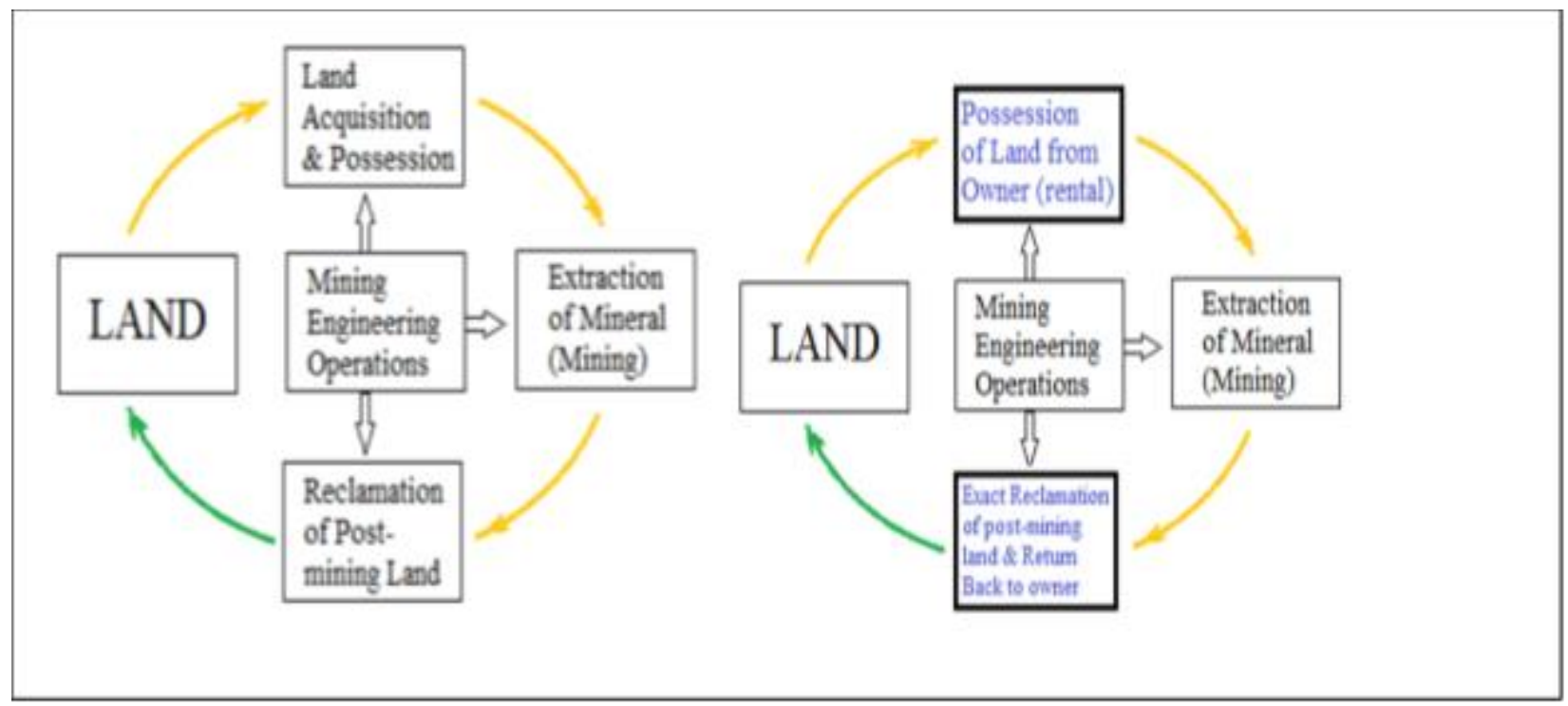

Source: (Singh et al., 2017), p.311)

For effectiveness, biological reclamation using selective plantations with fly ash and other fertility supplements is preferred because it improves the damaged mine physicochemical characteristics, enhances photosynthetic activity, and minimises runoff and soil erosion (Srivastava et al., 2014; Liu et al., 2017). However, Liu et al. (2017), argues that the recovery of soil organic matter and nitrogenmore so in the topsoil-is difficult to achieve in years. Therefore, following land reclamation, the land has to be restored to its previous state through the maintenance of biological reclamation; this requires the addition of minerals and water to the soil for several years to allow the regeneration of previous soil properties (Singh et al., 2017). The land is then said to be fully rehabilitated following the establishment of pre-mining vegetation and other inhabitants such that the pre-mining status of the land is fully simulated.

Elsewhere, a study by Feng et al. (2019) proposes a comprehensive system of mine soil reconstruction which involves five reclamation phases as follows;

- Reshaping

- Geomorphic Reconstruction of soil

77 | This work is licensed under a Creative Commons Attribution 4.0 International License. 
- Hydrological stability

- Restoration of vegetation

- Rebuilding of landscape

However, although land reclamation has been identified as a suitable solution to land degradation after coal mining, in Kenya where agriculture is the main economic activity, low organic content on reclaimed lands and shortage of agricultural land would mean lowered agricultural productivity. Therefore, the decision of whether to convert agricultural lands to coal mines should be critically considered before committing to coal mining activities.

\section{Coal mine wastes handling}

Coal mine waste is a major source of environmental pollution in most coal-producing countries. These wastes include coal slime, coal gangue, coalbed methane (CBM) and coal mine drainage (Haibin \& Zhenling, 2010). For example, according to a study by Qureshi et al. (2016), the oxidation of sulphidecontaining waste rocks results in acid mine drainage, which is a prevalent environmental problem in coal mining. Therefore, to reduce the environmental impacts associated with coal mine

Table 2: Criterion for evaluating CMWR usage wastes and to reduce the economic burden of managing the wastes, several wastes handling approaches have been applied in some high coalproducing countries; which would apply to Kenya as follows;

\section{Coal Mine Waste Rock (CMWR) reduction and utilisation}

This is an engineering technique that involves the reduction and utilisation of coal mine waste rock (gangue) to minimise its environmental impacts. CMWR is a mixture of different types of rocks mainly comprising of inorganic materials $\left(\mathrm{SiO}_{2}\right.$, $\mathrm{FeO}_{3}, \quad \mathrm{Al}_{2} \mathrm{O}_{3}$, impurities) and some organic materials, which requires a proximate analysis of specific coal mines to determine usage (Fan et al., 2014). Additionally, the application of CMWR reduction technique must put into consideration the local environment conditions (i.e. local market, local level of technology, financial status and local policy) and the design of mines (Fan et al., 2014).

To determine CMWR usage, researchers have identified different ways of usage classification. However, Li and Han, 2006 identified composition as the most suitable way of evaluating CMWR potential usage as shown in Table 2.

\begin{tabular}{|c|c|c|}
\hline Concentration & Criterion & Potential usage or product \\
\hline \multirow[t]{2}{*}{ Fixed carbon content $\left(\mathrm{FC}_{\mathrm{ad}}\right)$} & $>15 \%$ & Fuel in combustion boiler \\
\hline & $6 \%-15 \%$ & Mixed with other fuel in combustion boiler \\
\hline Sulfur content $\left(S_{\mathrm{t}, \mathrm{d}}\right)$ & $>6 \%$ & $\begin{array}{l}\text { Sulfur can be recovered through the gravity separation } \\
\text { process }\end{array}$ \\
\hline \multirow[t]{2}{*}{$\begin{array}{l}\text { Ratio of } \mathrm{Al}_{2} \mathrm{O}_{3} \text { content to } \mathrm{SiO}_{2} \\
\text { content }\end{array}$} & $>0.7$ & $\begin{array}{l}\text { Top-grade ceramic products, synthesising series molecular } \\
\text { sieve, farm fertilizer }\end{array}$ \\
\hline & $>0.3$ & $\mathrm{Al}$ series cleansing agent \\
\hline \multirow[t]{3}{*}{ Total content of $\mathrm{CaO}$ and $\mathrm{MgO}$} & $<2 \%$ & Sintered brick \\
\hline & $<12 \%$ & Baking-free brick \\
\hline & $>12 \%$ & Input material for producing special cement, mineral wool \\
\hline
\end{tabular}

Source: (Fan et al., 2014)

The use of CMWR in brick making and electricity generation are suitable revenue-generating activities for economic development. For example, in Tiefa coalfield China, 1.377 million tons of CMWR are used for brick making per year which generates a net profit of 5.54 million pounds (Fan et al., 2014), while the use of CMWR as a fuel admixture for power generation in the coalfield generates a net profit of 2.19 Million pounds per year. Social and environmental benefits of CMWR reduction and utilisation include the reduction in the area occupied by CMWR and reduction in $\mathrm{H}_{2} \mathrm{~S}$ and $\mathrm{SO}_{2}$ emissions from CMWR combustion (Fan et al., 2014). 
If applied in Kenya, CMWR reduction and utilisation would provide economic, socio and environmental benefits as evidenced above. However, the technique has been associated with secondary pollution and therefore successful coal mining development and significant economic benefits from CMWR require the collaboration of several enterprises including coal miners, power plants, CMWR users and the support of the government (Fan et al., 2014).

\section{Coal Sludge Slurry}

Coal sludge slurry is a black by-product of coal washing. It can contain toxic heavy metal elements (such as cadmium, iron, lead, chromium, arsenic, nickel and aluminium), organic compounds, hydrocarbons, and polyacrylamides (Knowlden et al., 2014). In most coal mines, coal sludge slurry is stored in ponds or abandoned mines, which pose a threat due to spilling or leaching into underground water sources. One perfect example of water contamination with coal slurry was the coal slurry spill in West Virginia creek where more than 100,000 gallons of slurry was introduced into the river leaving more than 300,000 people without clean water for more than a week $(\mathrm{CNN}, 2014)$.

To address such problems of underground water and aquifer contamination from coal slurry stored in abandoned coal mines or ponds, passive or active treatment methods are used. Passive treatment methods are commonly used because they are less costly compared to active treatment, but their effectiveness requires the understanding of the mine water chemistry and the availability of technologies (Hedin et al., 2013). According to Hedin et al. (2013), the following five passive treatments of coal slurry have been proven effective;

- Settling ponds: this involves the removal of dissolved organics or Fe through oxidation, and removal of aluminium hydroxide solids and ferric by allowing them to settle on the bottom.
- Constructed wetlands: these are used together with settling ponds, and they allow the settlement of residual suspended solids that could not settle in the ponds. The aerobic conditions provided allows biofiltration to remove heavy metals, ammonia, nitrogen and neutralisation of the mine water acidity

- Vertical flow ponds: these do not remove organic materials and have to be used together with settling ponds. Limestone is used to make the slurry more alkaline and allow the removal of ferrous and aluminium objects.

- Anoxic limestone drain: sub-surface limestone is used to neutralise acidity especially from anoxic waters comprising of manganese or ferrous iron.

- Oxic limestone bed: surface limestone is used to neutralise slurry $\mathrm{PH}$ and remove manganese at a faster rate than in constructed treatment wetlands. If drained regularly, oxic limestone beds are also more effective than anoxic limestone drains in the removal of aluminium and ferric iron.

However, to design a passive coal slurry treatment system, careful evaluation of slurry chemical composition as shown in Figure 3 is required. Coal slurry management through treatment in Kenyan mines is, therefore, possible. However, availability of technology, availability of finances to put-up the systems, and availability of technical expertise to analyse the chemical composition of the slurry are three factors that should not be ignored if slurry treatment is to be a success. In addition to coal slurry treatment, Khan et al. (2020) proposes other measures as regular monitoring of potentially toxic elements in water around active and abandoned coal mines, regulation of public mining and proper training on protection of the environment in an effort to curb human-induced effects associated with coal mining on ecological resources. 
Figure 2: Decision tree on the design of passive coal slurry treatment system

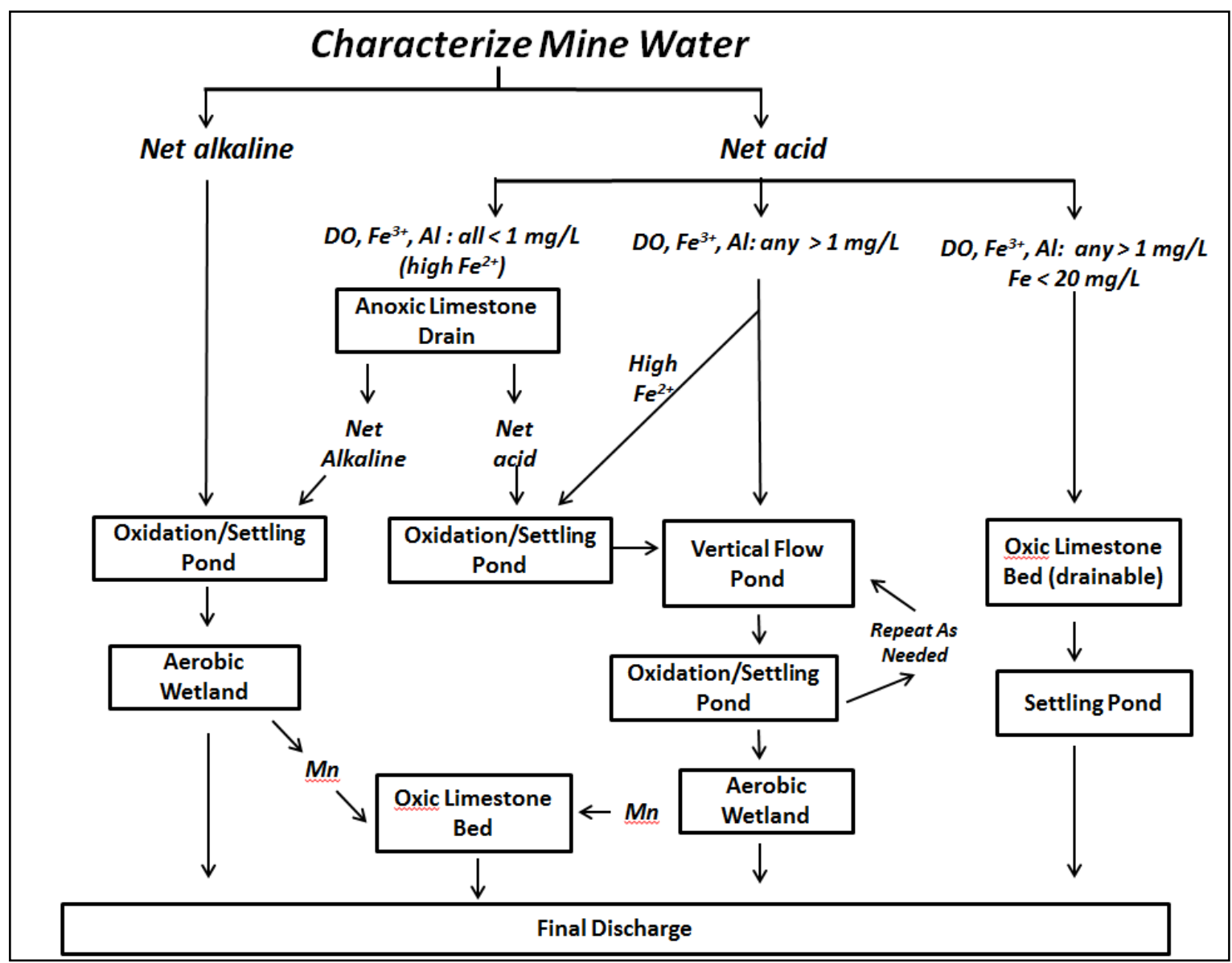

Source: (Hedin et al., 2013, p. 3)

\section{Coalbed Methane (CBM)}

Coal mining is often associated with accidents and GHGs emissions resulting from coal and gas outbursts. CBM is considered both a clean energy resource and a major environmental hazard in coal mining (Guo et al., 2014). With CBM extraction concerns mainly categorized into two, coal mining safety is considered as the main concern associated with coal and CBM extraction in China. However, in some cases, CBM extraction involves surface drilling whose main aim is to obtain the CBM resource To address the safety concern, coal mining in China involves methane gas extraction before mining, during mining and after mining, and the methane is put to several uses (Zhou et al., 2014). Extracting CBM before mining reduces coal seam pressure and CBM content, reduces the danger of outbursts and reduces coal mining CBM emissions (Wang et al., 2014). During mining, the extraction of CBM enhances mine safety by minimising CBM emission into the workface and improving the rate of CBM extraction; while CBM extraction after mining helps to keep the goaf airtight (Wang et al., 2014). Because there exist different applicable methods of CBM extraction techniques, the choice of a suitable method depends on several factors (based on distinctive principles of division) as shown in Table 3. 
Table 3: Comprehensive CBM extraction from mines

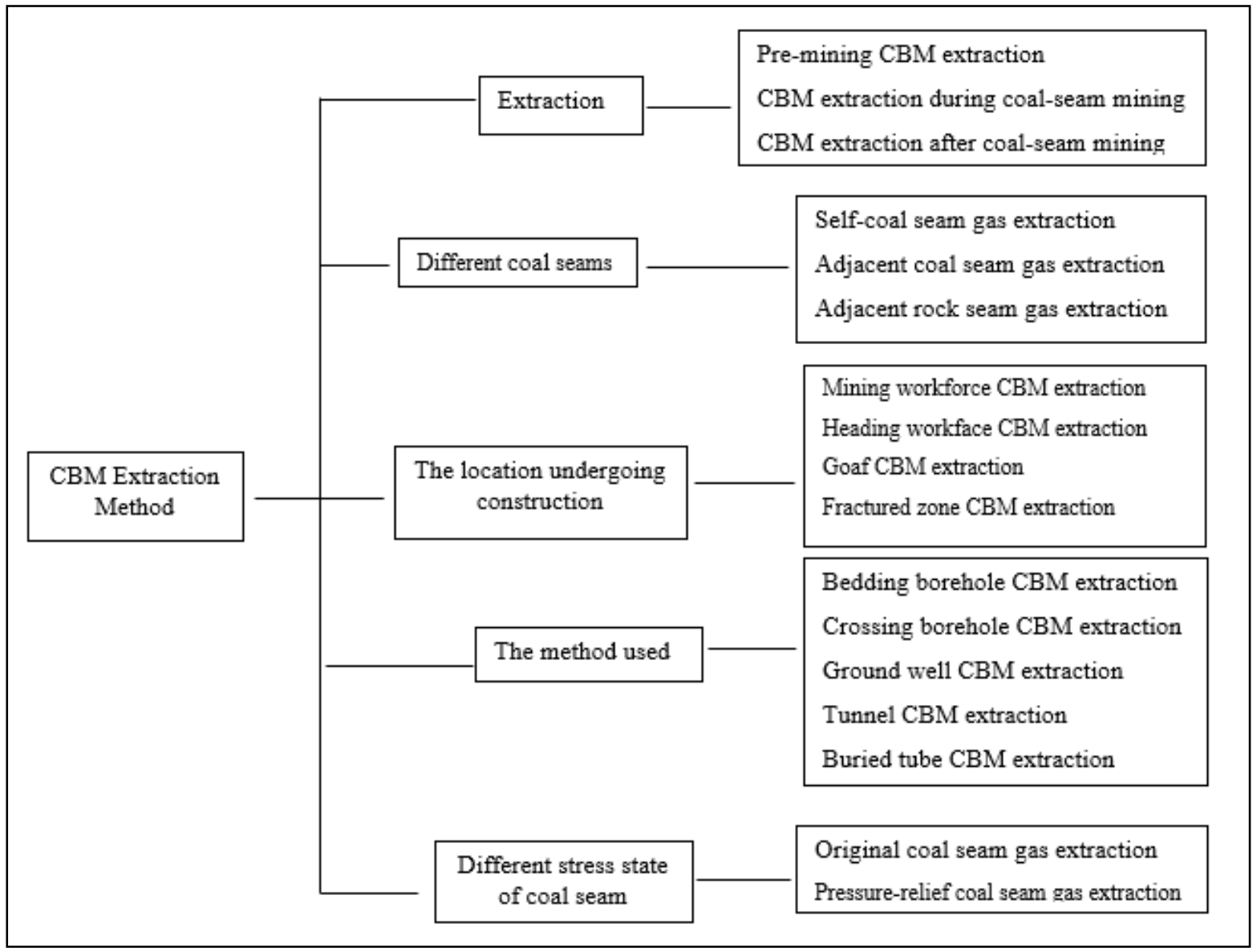

Source: Redrawn from Wang et al. (2014, p.201)

Apart from enhancing safety, in China, CBM recovery helps in energy recovery whereby extracted methane is used for cooking and heating households, power generation in industries, fuel for automobiles and as an industrial fuel (Zhou et al.,
2014), as shown in Figure 4. However, Zhou et al. (2014, p. 363) further notes that the choice of CBM utilisation method is largely dependent on the availability of appropriate technology and capital investment.

81 This work is licensed under a Creative Commons Attribution 4.0 International License. 
Figure 4: Methane drainage and utilisation in China

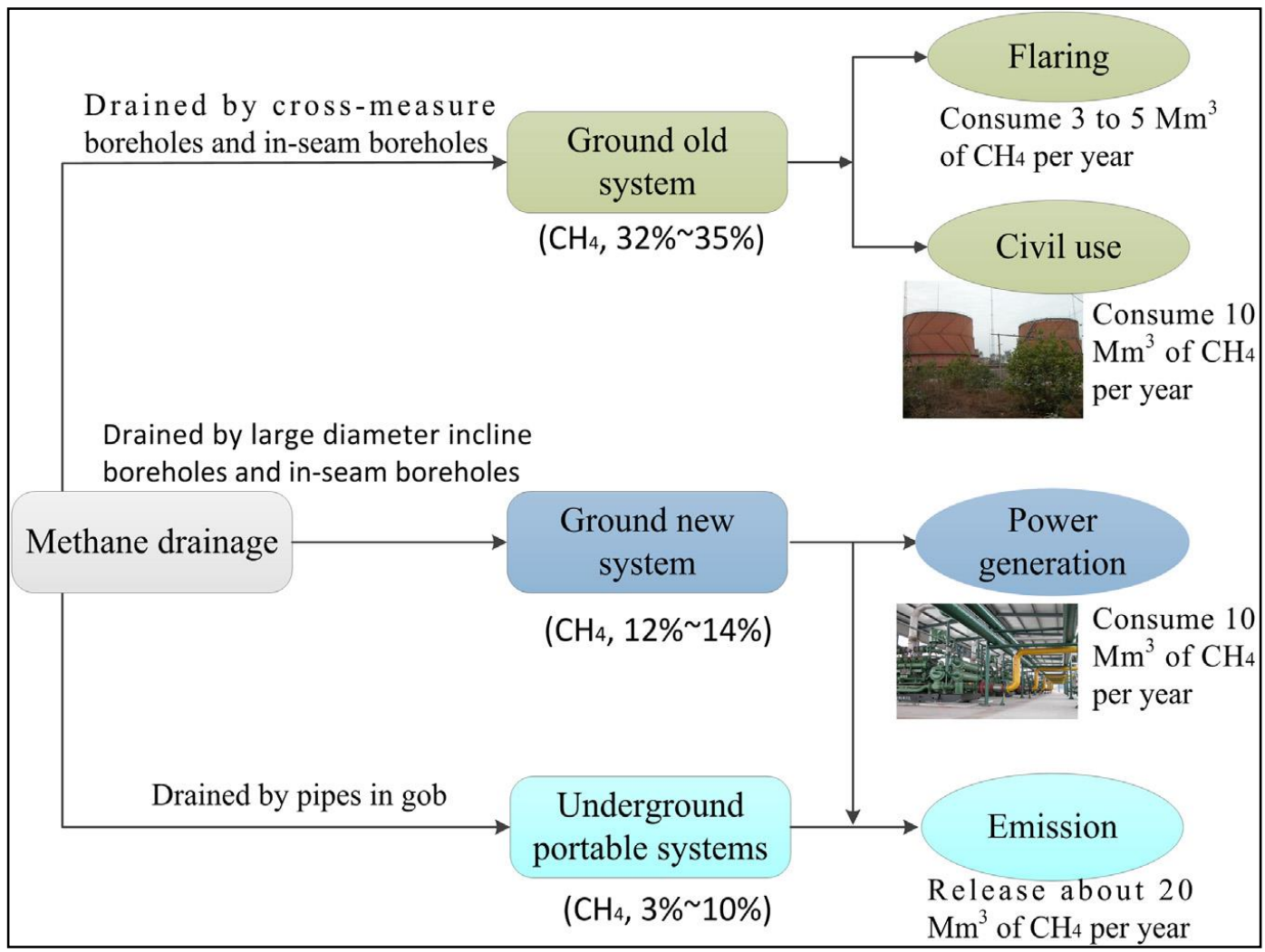

Source: (Zhou et al., 2014)

Therefore, Kenya can enhance safety in coal mines through CBM extraction while providing additional energy sources as has been proven effective in other countries. However, many factors including availability of CBM extraction technology and financial investments, timing and location of coal seams should be considered; as they determine the type of method to be used and the most suitable use of CBM obtained.

\section{Coal Mine Drainage (CMD)}

Coal mine wastewater which includes water from surface construction works, sanitary facilities, open pits and water from underground mines form one of the main environmental challenges in coal mining. In most coal-producing developed countries, CMD is treated and managed. Some of the uses of treated mine water include irrigation, domestic use, dust control, industrial production and purification of the environment (Haibin \& Zhenling, 2010; Mien, 2012).

According to a study conducted in Vietnam on the management of coal mine drainage, the choice of mine drainage treatment technology is dependent on season, quality, and amount of CMD being treated (Mien, 2012). These technologies range from simple treatment for the supply of low utilisation efficiency industrial and agricultural water to advanced treatment for the supply of high utilisation efficiency water for domestic use (Q. Feng et al., 2014). The suitability of CMD usage is dependent on its utilisation efficiency, and the Ministry of Land and Resource in China defined a formula for the determination of utilisation efficiency as follows;

$$
\text { Utilisation efficiency }=\frac{\text { Generated CMD flow }- \text { Discharged CMD flow }}{\text { Generated CMD flow }}(\text { Feng et al. , 2014) }
$$


However, Q. Feng et al. (2014), acknowledges that successful application of these CMD treatment technologies requires backing up by proper laws and regulations. In the case of Kenya where coal reserves are mainly located in ASAL areas, the unavailability of water is a major challenge that could interfere with coal mining in the country. The problem of water shortage for use in the mines can therefore be addressed through the treatment of CMD. However, although CMD treatment has been proven effective in other countries, the availability of treatment technologies in Kenya is a significant factor to be considered; not forgetting that such technologies will require the establishment of proper laws and regulations to govern them.

\section{CONCLUSION}

As Kenya strives to become an industrialised middle-income country as stipulated in her Vision 2030 development agenda, the discovery of coal reserves in the country provides a suitable opportunity for the country to address its energy security challenges. Although the discoveries come at a time when the global focus is the shift from 'dirty' energy (fossil fuels) towards renewable energy in a bid to mitigate human-induced global warming and climate change; it is also a time when technological advances have seen the exploitation of coal energy with minimal environmental implications.

From the discussion, there are many approaches and technologies applicable for coal mining in Kenya with minimal environmental impacts as demonstrated in other coal-producing countries. These range from the use of fully mechanised underground coal mining technology, land reclamation, rehabilitation and restoration after mining; and coal mine wastes reduction and utilisation. However, many factors come into consideration in determining the feasibility of sustainable coal mining in Kenya. First, whether Kenya's coal reserves will guarantee energy security in the country or it will be just but a 'stopgap' is one factor that Kenya should consider before shifting her focus from renewable energy and embarking on massive investments in coal mining technologies. Second, the question of whether Kenya should focus on coal power generation to meet her energy demands largely depends on how well she is prepared financially to invest in sustainable coal mining technologies or how much she is willing to steer her economic growth at the expense of local and global environmental health. Third, most clean coal technologies require a high level of technical expertise, favourable physical environmental conditions, and backing up with proper policies and regulations which should be put into consideration before embarking on coal mining.

\section{ACKNOWLEDGEMENT}

This research received no specific grant from any funding agency.

\section{REFERENCES}

Adibee, N., Osanloo, M., \& Rahmanpour, M. (2013). Adverse effects of coal mine waste dumps on the environment and their management. Environmental Earth Sciences, 70(4), 1581-1592.

Banerjee, D. (2014). Acid drainage potential from coal mine wastes: Environmental assessment through static and kinetic tests. International Journal of Environmental Science and Technology, 11(5), 1365-1378.

Basu, A., Marett, J. D., \& Wehner, S. (2016). Access to clean energy in rural Kenya through innovative market-based solutions. http://www.undp.org/content/dam/LECB/docs/p ubs-namas/undp-lecb-Kenya_Clean-EnergyNAMA-2016.pdf?download.

Bian, Z., Inyang, H. I., Daniels, J. L., Otto, F., \& Struthers, S. (2010). Environmental issues from coal mining and their solutions. Mining Science and Technology (China), 20(2), 215-223. https://doi.org/10.1016/S1674-5264(09)60187-3

Chaulya, S., \& Prasad, G. (2016). Chapter 1-Slope Failure Mechanism and Monitoring Techniques. Sensing and Monitoring Technologies for Mines and Hazardous Areas; Elsevier: Amsterdam, The Netherlands, 1-86.

Chugh, Y. P., \& Behum, P. T. (2014). Coal waste management practices in the USA: An overview. International Journal of Coal Science \& 
Technology, 1(2), 163-176. https://doi.org/10.1007/s40789-014-0023-4

Ciesielczuk, J., Czylok, A., Fabiańska, M. J., \& Misz-Kennan, M. (2015). Plant occurrence on burning coal waste-a case study from the Katowice-Wełnowiec dump, Poland. Environmental \& Socio-Economic Studies, 3(2), $1-10$.

CNN, F. K. C. (2014, February). Officials: Coal slurry spill blackens West Virginia creek. CNN. https://www.cnn.com/2014/02/11/us/westvirginia-slurry-spill/index.html

Coal Association of Canada. (2012). Economic impact analysis of the coal mining industry in Canada.

http://www.mining.bc.ca/sites/default/files/reso urces/pwc_cac_report_final_oct_2012.pdf

Drebenstedt, C. (2001). Negative impacts of opencast mining on the environment and their mitigation. In The exploitation of natural resources and the consequences (Vol. 1-0, pp. 417-426). Thomas Telford Publishing. https://doi.org/10.1680/teonratc.30046.0062

Eije, S. V. \& Mokveld, K. (2018). Final Energy report Kenya. 37.

EPRA. (2019). Energy and Petroleum Statistics Report 2019. Energy and Petroleum Regulatory Authority. $\quad$ https://www.epra.go.ke/wpcontent/uploads/2020/09/Energy-and-

Petroleum-Statistics-Report-2019-1.pdf

Fan, G., Zhang, D., \& Wang, X. (2014). Reduction and utilization of coal mine waste rock in China: A case study in Tiefa coalfield. Resources, Conservation and Recycling, 83, 24-33. https://doi.org/10.1016/j.resconrec.2013.12.001

Feng, Q., Li, T., Qian, B., Zhou, L., Gao, B., \& Yuan, T. (2014). Chemical Characteristics and Utilization of Coal Mine Drainage in China. Mine Water and the Environment, 33(3), 276286. https://doi.org/10.1007/s10230-014-0271-y

Feng, Y., Wang, J., Bai, Z., \& Reading, L. (2019). Effects of surface coal mining and land reclamation on soil properties: A review. Earth-
Science Reviews, 191, 12-25. https://doi.org/10.1016/j.earscirev.2019.02.015

Guo, P., Cheng, Y., Jin, K., \& Liu, Y. (2014). The impact of faults on the occurrence of coal bed methane in Renlou coal mine, Huaibei coalfield, China. Journal of Natural Gas Science and Engineering, 17, 151-158. https://doi.org/10.10 16/j.jngse.2013.12.003

Haibin, L., \& Zhenling, L. (2010). Recycling utilization patterns of coal mining waste in China. Resources, Conservation and Recycling, 54(12), 1331-1340. https://doi.org/10.1016/j.res conrec.2010.05.005

Hedin, R., Weaver, T., Wolfe, N., \& Watzlaf, G. (2013). Effective passive treatment of coal mine drainage. 22-25.

Huang, J., Tian, C., Xing, L., Bian, Z., \& Miao, X. (2017). Green and Sustainable Mining: Underground Coal Mine Fully Mechanized Solid Dense Stowing-Mining Method. Sustainability, 9(8), 1418. https://doi.org/10.339 0/su9081418

Jabbar Khan, A., Akhter, G., Gabriel, H. F., \& Shahid, M. (2020). Anthropogenic Effects of Coal Mining on Ecological Resources of the Central Indus Basin, Pakistan. International Journal of Environmental Research and Public Health, 17(4), 1255. https://doi.org/10.3390/ijer ph17041255

Jaccard, M. (2006). Sustainable fossil fuels: The unusual suspect in the quest for clean and enduring energy. Cambridge University Press.

Kiplagat, J. K., Wang, R. Z., \& Li, T. X. (2011). Renewable energy in Kenya: Resource potential and status of exploitation. Renewable and Sustainable Energy Reviews, 15(6), 2960-2973. https://doi.org/10.1016/j.rser.2011.03.023

Knowlden, S., Ryan, T., \& O’Donnell, M. (2014). An Analysis of Constructed Treatment Wetlands to Purify Coal Slurry. https://blogs.umass.edu/n atsci397a-eross/an-analysis-of-constructedtreatment-wetlands-to-purify-coal-slurry/

Li, N., \& Han, B. (2006). Chinese research into utilisation of coal waste in ceramics, refractories

84 This work is licensed under a Creative Commons Attribution 4.0 International License. 
and cements. Advances in Applied Ceramics, 105(1), 64-68.

Liu, X., Bai, Z., Zhou, W., Cao, Y., \& Zhang, G. (2017). Changes in soil properties in the soil profile after mining and reclamation in an opencast coal mine on the Loess Plateau, China. Ecological Engineering, 98, 228-239. https://doi.org/10.1016/j.ecoleng.2016.10.078

MacKay, D. (2008). Sustainable Energy-without the hot air. UIT Cambridge.

Massachusetts Institute of Technology. (2016). Environmental Risks of Mining. http://web.mit.edu/12.000/www/m2016/finalwe bsite/problems/mining.html

Mien, T. (2012). Mine waste water management and treatment in coal mines in Vietnam. Geosystem Engineering, 15(1), 66-70. https://doi.org/10.10 $80 / 12269328.2012 .674430$

Ministry of Energy and Petroleum. (2015). National energy and petroleum policy, Republic of Kenya, 2015. http://www.erc.go.ke/images/docs/Nation al_Energy_Petroleum_Policy_August_2015.pdf

Oxford Business Group. (2015, July 30). Kenya looks to greater generation capacity. Oxford Business Group. https://oxfordbusinessgroup.co $\mathrm{m} /$ news/kenya-looks-greater-generationcapacity

Qureshi, A., Maurice, C., \& Öhlander, B. (2016). Potential of coal mine waste rock for generating acid mine drainage. Journal of Geochemical Exploration, 160, 44-54. https://doi.org/10.1016 /j.gexplo.2015.10.014

Reddy, P. J. (2013). Clean coal technologies for power generation. CRC Press.

Singh, P. K., Mishra, A. K., \& Singh, D. R. (2017). A new model of exact reclamation of postmining land to address land acquisition problem in Indian coal mining industry. Journal of the Geological Society of India, 89(3), 307-314. https://doi.org/10.1007/s12594-017-0604-0

Song, Y.-S., Cho, Y.-C., \& Kim, K.-S. (2015). Monitoring and Stability Analysis of a Coal Mine Waste Heap Slope in Korea. In
Engineering Geology for Society and Territory-Volume 2 (pp. 217-220). Springer, Cham. https://doi.org/10.1007/978-3-31909057-3_30

Srivastava, N. K., Ram, L. C., \& Masto, R. E. (2014). Reclamation of overburden and lowland in coal mining area with fly ash and selective plantation: A sustainable ecological approach. Ecological Engineering, 71, 479-489. https://doi.org/10.1016/j.ecoleng.2014.07.062

Torrie, M. (2014). Future of Kenyan electricity generation: An analysis of physical and economical potential and least cost sources.

U.S. EIA. (2020). Coal and the environment-U.S. Energy Information Administration (EIA). https://www.eia.gov/energyexplained/coal/coaland-the-environment.php

Wang, H., Cheng, Y., Wang, W., \& Xu, R. (2014). Research on comprehensive CBM extraction technology and its applications in China's coal mines. Journal of Natural Gas Science and Engineering, 20, 200-207. https://doi.org/10.10 16/j.jngse.2014.05.025

Williams, G., \& Nikijuluw, R. (2020). Economic and social indicators between coal mining LGAs and non-coal mining LGAs in regional Queensland, Australia. Resources Policy, 67, 101688. https://doi.org/10.1016/j.resourpol.202 0.101688

Zhang, J., Zhang, Q., Sun, Q., Gao, R., Germain, D., \& Abro, S. (2015). Surface subsidence control theory and application to backfill coal mining technology. Environmental Earth Sciences, 74(2), 1439-1448. https://doi.org/10.1007/s1266 5-015-4133-0

Zhou, H., Yang, Q., Cheng, Y., Ge, C., \& Chen, J. (2014). Methane drainage and utilization in coal mines with strong coal and gas outburst dangers: A case study in Luling mine, China. Journal of Natural Gas Science and Engineering, 20, 357365. https://doi.org/10.1016/j.jngse.2014.07.023

85 | This work is licensed under a Creative Commons Attribution 4.0 International License. 